\title{
Rethinking monetary theory in light of Keynes and the crisis
}

Marc Lavoie $^{\dagger}$

\begin{abstract}
The purpose of the present paper is to examine the main changes that have occurred or that need to occur in monetary economics, and to do this in light of what Keynes told us 80 years ago in his General Theory, or even more than 85 years ago when he wrote the Treatise on Money. Inflation targeting and central bank independence are re-examined, as are the standard views of the money multiplier and of the fractional-reserve system. Unconventional monetary policies, although previously suggested by Keynes, appear to be a disguised return to Monetarism and the actual impact of quantitative easing must be understood in light of a theory of endogenous money with monetary implementation occurring within a framework where the target interest rate is set at the floor of the corridor.
\end{abstract}

Keywords: Inflation Targeting, Endogenous Money, Quantitative Easing, Money Multiplier, Potential Output

JEL Classification: E31, E51, E52, E58.

\footnotetext{
*This paper arises from two presentations that were made during the Jornadas Monetarias y Bancarias organized by the Banco Central de la República Argentina in November 2013 and in June 2015, and also from a presentation that was made at the workshop on 'Keynes's General Theory eighty years later: what lessons for the contemporary world?', This research has been sponsored by various grants from the Institute for New Economic Thinking (INET).

${ }^{\dagger}$ Emeritus Professor at the University of Ottawa, and Senior Research Chair, Université Paris Sorbonne Cité, Université Paris 13 (Centre d’Économie de Paris Nord).
} 


\section{Introduction}

The purpose of this paper is rather simple. The financial crisis that erupted in 2008 has been a shock to those who held that financial markets were efficient and who thought that markets could be safely left to evolve on their own. Pragmatism had led to the reconsideration of several tenets of macroeconomic theory as seen by the mainstream. The purpose of the present paper is to examine the main changes that have occurred or that need to occur in monetary economics, and to do this in light of what Keynes told us 80 years ago in his General Theory, or even more than 85 years ago when he wrote the Treatise on Money.

The paper is devoted to current monetary theory and policy, examining what seems to have been changed or been questioned as a consequence of what has happened during the crisis. I will deal with the following points: the current goal of central banks, that is, inflation targeting, as well as alternative objectives, that is, financial stability and full employment; the concept of central bank independence when government intervention has been necessary; the relevance of endogenous money and its critique of the money multiplier and of the fractionalreserve banking system; the controversy over the use and usefulness of unconventional policies and quantitative easing. I conclude by recalling that Keynes himself, more than 80 years ago, when faced with a large recession, abandoned monetary policy and switched over to advocate expansionary fiscal policies.

\section{Inflation targeting}

Ever since the early 1990s, explicit inflation targeting has been progressively adopted by a large number of central banks, at least among fully industrialized countries. The USA was a late comer, but ultimately, in 2012, the Federal Reserve moved from an implicit to an explicit target. In most countries, including the Eurozone, the target has been set at or below two per cent or within a corridor with the center set at two per cent. A number of authors wonder whether the success in achieving the inflation target is really due to the new procedures or whether it was due to some degree to sheer luck, made possible for instance by the cheap exports of consumer goods coming from China, as a number of empirical studies have shown that countries without inflation targeting did just as well in reducing and maintaining inflation rates (Seccareccia and Lavoie, 2010).

Another question has been whether the two per cent inflation target is too low a target. The question has arisen in the context of the crisis, when it was found that with nominal interest rates at zero, at best the real interest rate could not be any lower than minus two per cent. This slightly negative real rate was thought to be insufficiently negative to allow for a strong monetary response to a large slowdown - an argument which is no different from the one that was offered by Don Patinkin (1948) to explain how economies could deviate from full employment. Patinkin thought that in some circumstances the full employment saving and investment curves crossed each other at a negative real rate of interest. Thus several economists have argued in favour of a four per cent inflation target so as to lower the probability of getting into this zero-bound constraint (Ball, 2014). By contrast, central bankers who have managed to get inflation down to around two per cent, sometimes at a high cost for the economy, are rather reluctant to make the change. They argue that moderate inflation at that higher level is likely to creep up, so that such a proposition would be counterproductive and useless, since severe crises are a rare event.

A number of economists have argued that a better alternative to inflation targeting is price-level targeting. A central bank would target a given level of the consumer price index. A variant of this would be to target a consumer price path. Assuming forward-looking and 
rational expectations, price targeting is said to be more efficient than inflation targeting, thus inducing a few central banks to seriously consider such an alternative. In the straight pricetargeting variant, an increase in the price level would generate a response from the central bank so as to achieve a decrease in the price level in the following periods, so as to regain the target price target. In other words, such a central bank would be orchestrating a deflation. In the summer and fall of 2007, just as some interbank markets were freezing and the financial system was on the verge of collapsing, deputy governors at the Bank of Canada were making speeches about the advantages of price-level targeting. Indeed, even as late as 2011, the Bank of Canada (2011) still seemed to consider as a worthwhile idea the notion of a consumer price path target, going so far as to give credence to a Bank's study that 'demonstrated' that the optimal path target would be a deflation rate of approximately two per cent per year, that is, roughly the growth rate of labour productivity. Older readers will see the similitudes with the negative inflation rule that was advocated by Milton Friedman in his Optimal Quantity of Money back in the 1950s. Inspection of the Bank of Canada's study shows that the model utilized to arrive at such a conclusion is a New Keynesian model with no money, no other financial asset, no credit, no debt and no risk of default! What else needs to be said?

The fear of debt deflation - the fear that lower wages and prices with debts fixed in nominal terms would lead to a depression, as a result of higher real debt burdens, debt defaults by the private sector, thus putting banks in jeopardy - seems to have removed pricelevel or price-path targeting and its imaginary benefits from the agenda, along with a lower inflation target. The new fad, or so it seems, is nominal GDP targeting. Nominal income is then the target. This is simply a return to Monetarism, in new clothes. Monetarists of the 1970s and 1980 s, as is well known, used to advocate growth targets in the money supply. Their arguments then were that such monetary targets would stabilize the growth rate of nominal GDP, and hence would stabilize the growth rate of prices since they assumed that real output would roughly grow at its exogenously-given potential growth rate. Nominal GDP targeting is thus Monetarism in new clothes: old wine in a new bottle.

What about Keynes? In the Treatise on Money, Keynes was mainly concerned with the control of the price level, the variations of which he mainly attributed to a discrepancy between saving and investment, which he called profit inflation, with the latter being heavily influenced by the long-term interest rate. At the time this part of Keynes's writings sounded very much like a modified Wicksellian proposal, and it is doubtful that the Keynes of 1930 would have objected to the inflation targeting policies pursued by modern central banks. With the advent of the economic crisis of the 1930s - The Great Depression - Keynes's focus changed completely. In his General Theory of 1936, Keynes became preoccupied instead with the level of employment. As such the Keynes of 1936 would agree with the concerns of most heterodox economists, that is, he would also most certainly have wondered whether inflation targeting is the best thing a central bank can do.

\section{Financial stability and full employment as targets?}

Since the mid-1980s, the mantra of most central bankers is that 'low, stable and predictable inflation is the best contribution that monetary policy can make to the economy'. This claim used to be based on the assertion that lower inflation would generate higher growth rates of productivity. While the 1973 to 1982 period did generate such a negative relationship, as the oil shocks led to increases in inflation rates and a simultaneous decrease in productivity growth, empirical research on this topic seems to have entirely vanished, no doubt because the relationship could not be replicated for later periods. But the mantra has subsided regardless. Besides the fact that overly restrictive monetary policies designed to lower inflation 
may slow down the economy, and, through the Kaldor-Verdoorn effect, are likely to slow down productivity growth, we now know that inflation targeting is quite unable on its own to achieve financial stability, having been accompanied by financial asset bubbles and real estate bubbles, along with excessive debt-taking by private agents, in particular households and financial institutions. This reckless behaviour ended up having a destructive impact on real activity, an impact from which many economies have not yet fully recovered. Thus the stability of the financial system may be a much more important objective than price stability for a central banker.

There is little doubt that Keynes would agree with those who today emphasize that price stability did not bring about financial stability as a side effect, and who would put financial stability to the forefront of central bank objectives. Keynes, both in 1930 and 1936, clearly thought that the banking and financial systems left on their own would tend towards instability. Keynes is well known for having argued in Chapter 12 of the General Theory that the financial system, notably the stock market, was akin to a casino. When commenting on the role of animal spirits and speculation in the investment decisions on Wall Street, Chapter 12 of the General Theory, Keynes (1936, p. 159) famously wrote that 'when the capital development of a country becomes a by-product of the activities of a casino, the job is likely to be ill-done'.

There is little doubt that this describes precisely what has happened to our modern financial systems, with their numerous derivatives, as we all found out in 2008. Whereas a few fund managers were warning about the dangers arising from these highly risky activities, they were not listened to, as bankers and financiers had to keep dancing as long as the music played. As Keynes (1936, p. 158) also said, 'worldly wisdom teaches that it is better for reputation to fail conventionally than to succeed unconventionally'. Indeed, in the earlier Treatise on Money, Keynes (1930b, p. 361) had made the same claim, arguing that financial markets were likely to purposefully act in a disrupting way, writing that 'so long as the crowd can be relied on to act in a certain way, even if it is misguided, it will be to the advantage of the better informed professional to act in the same way'.

Thus while Keynes thought that financial actors were rational, he also thought that financial markets did not in any way respond to the efficient market hypothesis. He did not believe that financial markets generated proper information or the right price, and he certainly did not believe that financial markets left on their own promoted public interest. But even leaving speculation aside, Keynes was quite aware that modern banking systems were prone to over-expansion. This was already the case in the 1920s, and there is no reason to think that it is any different today. As Keynes said, in a monetary system where all payments are made by cheques, credit cards, or electronically, and where there is no need for cash reserves, the system 'would possess an inherent instability' (Keynes 1930a, p. 27).

Besides financial stability, it can certainly be argued that the objective of full employment is a much more relevant and useful objective than price stability for most of the population. The Federal Reserve in the US has this dual objective of full employment and price stability. But many other central banks do not, although it must be recognized that during the Global Financial Crisis, some central banks took expansionary measures under the pretext that they intended to bring back a falling inflation rate towards its target, while a naïve observer would have thought that these had been taken to stop the economy from falling into a depression and reaching double-digit unemployment rates. A pragmatic proposal, taking into account the fact that most central bankers would be reluctant to give up inflation targeting would be to say that central banks ought to continue to target inflation, while seeking the maximum levels of output and employment consistent with this target' (Clinton 2006, p. 20). 
There is substantial empirical evidence now that Phillips curves have a long midsegment which is completely flat, meaning that there is a large range of unemployment rates or of rates of capacity utilization such that increases or decreases in these rates will not lead to a deceleration or acceleration of the inflation rate (Peach et al., 2011). Whether this is due to the fact that most firms face constant marginal costs, that expected inflation is well anchored at the target rate set by central bank, or that potential output reacts positively to higher actual output, does not really matter. The lesson is that a central bank overly concerned with inflation is likely to engineer pre-emptive strikes against forecasted inflation that unnecessarily reduce output and employment. Since there is no evidence that achieving low inflation is the best thing that a central bank can do for the welfare of its citizens, as the speculative frenzy of the Great Moderation and the Global Financial Crisis that followed has shown, full employment ought to be a an explicit part of the mandate of all central bankers.

\section{Central bank independence}

Scholars in the rules and discretion literature as well as international organizations have put substantial pressures on governments to force them to adopt rules of governance that would make as much as possible central banks independent from political influence. This has culminated in the rules of governance that were adopted by the European Central Bank (ECB), with in addition the ECB being forbidden to purchase government securities on primary markets and with the ECB denying itself (until the Eurozone crisis had reached full scale), by convention, the possibility of proceeding to outright purchases of sovereign bonds on secondary markets.

The crisis has highlighted the fact that a central bank cannot be fully independent. Those of us who are concerned with the actual operations of central banks already knew this. In order to tame the movements of interest rates on overnight markets the central bank needs to know the daily amounts that the government plans to spend and the daily amounts that the government expects to receive in the form of taxes. In many countries the central bank moves government deposits from or towards their accounts at the central bank or at commercial banks in order to achieve a better control over the amount of reserves or high powered money in the system.

But the financial crisis revealed a degree of cooperation between the central bank and the government that went much beyond these technical daily operations. After the Lehman Brothers default, a number of central banks purchased private assets from commercial banks, selling to them Treasury bills in exchange, thus swapping doubtful assets for highly secure ones. These swaps allowed central banks to pursue credit easing without expanding the size of their balance sheet and thus the amount of free reserves. However, after a while, due to the unusual size of these operations, these central banks started to run out of Treasury bills. They were then forced to ask the Treasury to issue new government securities, even when the government was not running any deficit, thus increasing the gross public debt without modifying its net amount. The central bank would then purchase the newly-issued Treasury bills, with the proceeds of the sale being held as government deposits at the central bank. As a consequence of such an operation, the size of the balance sheet of the central bank would grow, but the amount of reserves in the system would stay put, and central bankers would keep control of the overnight interest rate. The central bank would then be able to resume its credit easing operations, easing off downward pressures on private assets by purchasing them in exchange for the safe Treasury bills that the commercial banks longed for.

It is interesting to note that Keynes was fully aware of the danger, for a central bank, of running out of T-bills, for as Keynes (1930b, p. 259) wrote in the Treatise on Money, 'For the 
success of open-market policy depends on the Central Bank always having in hand adequate ammunition in the shape of open-market securities available for sale'. Thus Keynes was concerned by the possibility that the central bank may run out of T-bills that it can sell, either to make swaps with long-term securities or to sterilize the inflow of gold or foreign currency in the context of an open economy and a balance-of-payment surplus. Keynes was thus aware that collaboration might be needed between the central bank and the government.

The financial crisis has clearly shown that central bank independence is illusory and should not be a goal on itself. There is also something undemocratic in asserting that central bankers alone should remain clear of political and popular pressures. ${ }^{1}$

\section{Endogenous money}

Post-Keynesians such as Nicholas Kaldor (1982) and Basil Moore (1988) have been arguing for decades that the money supply is endogenous and demand-determined (Lavoie, 2014, ch. 4). There is nothing new here, as Knut Wicksell was already making the same claims more than a hundred years ago when dealing with his pure credit economy. Indeed the idea that central bankers have little control over money goes back to Thornton and Tooke in the $19^{\text {th }}$ century. As my former co-author Wynne Godley (1997 (2012, p. 91)) has put it in ironical terms, "governments can no more "control" stocks of either bank money or cash than a gardener can control the direction of a hosepipe by grabbing at the water jet'. For a long time central bankers recognized the same, at the Fed or even at the Bundesbank, arguing that they were subjected to a reverse causality between reserves and money. This all changed for a while, under the frontal attack of the Monetarists and of textbook writers, when central bankers in the 1980s tried to persuade the public that they were not responsible for the high interest rates that had been brought about to fight the inflation of the 1970s that had been caused by two large oil shocks.

Unfortunately, Keynes was not of much help here. While one can certainly find passages in the Treatise on Money where Keynes does seem to provide support to an endogenous money view, as argued for instance by Basil Moore (1988) and Cardim de Carvalho (2013), this is not the case of the General Theory. For instance, when Keynes sums up his main arguments in Chapter 18, he indicates that there are three 'ultimate independent variables' in his system, the third one being 'the quantity of money as determined by the action of the central bank' (Keynes 1936, p. 246-7). The statement that money must be conceived as some exogenous variable is repeated a number of times, notably when Keynes (1936, p. 274) asserts that 'the quantity of money is not determined by the public' or when he says that 'in the case of money ... the supply is fixed' $(1936$, p. 230). This led authors like Kaldor to complain that Keynes assumed an exogenous money supply, as did the Monetarists.

Geoff Tily strongly disagrees with this Kaldorian interpretation of an 'exogenousmoney Keynes'. He writes that 'those who explicitly charge that Keynes took money as exogenous are grossly misrepresenting his whole economics' (Tily 2007, p. 218). Tily and a few other post-Keynesian authors say that a distinction must be made between a constant variable and a given variable, but these semantic pirouettes cannot hide the fact that Keynes used to be a staunch defender of the Quantity of Money in his earlier works, and that this gets reflected many years later in the General Theory. A possible explanation for this is that

\footnotetext{
${ }^{1}$ Indeed, some authors, for instance T.K. Rymes (1991), who was a teacher of mine, has gone so far as to argue that just as there is a Department of Finance, responsible for the budget and for fiscal policies, there should be an elected Minister, the Minister of Monetary Affairs, who would be responsible for monetary policy.
} 
Keynes's views were heavily influenced by his perception of the British economy. While Keynes admitted that Continental banking systems showed some elasticity, Keynes (1930b, p. 231) was persuaded that in the case of the British system 'it is not an exaggeration to say that the individual Member banks have virtually no power to influence the aggregate volume of bankmoney'.

The clock was however turned around once more with the advent of New Consensus models (the New Neoclassical synthesis), which also implicitly endorsed the notion of a demand-led endogenous money supply and which brought back Wicksellian features in their monetary analysis. The advent of the New Consensus view, it seems to me, was brought about by the realization that central bankers, through a pragmatic approach, had put in place an inflation-targeting regime, accompanied by the introduction of the short-term interest rate as the explicit operational target to achieve the inflation target. Interest rates had always been an operational target of sort, but before the 1990s it was an implicit target, known only to the central bank and hence a target that was subjected to a lot of guesswork on the part of the financial market participants.

The explicit move away from the money supply targeting rule of the Monetarists, back towards interest rate targeting, as had been defended by the Radcliffe commission in the 1950s, has sometimes been explained through some elementary IS/LM model, by claiming that the move had been necessitated by the rising instability in the demand for money (Poole, 1970). But the necessity to have interest rate targeting is not due to these macroeconomic reasons: it has to do with the nitty-gritty of central banking; it is related to the daily or even hourly operations of a central bank and it is related to the fact that any transaction involving the central bank or the government account at the central bank, be it to manage the exchange rate by buying or selling foreign currency, to pay civil servants and other government expenditures or to collect taxes, will have an impact on the amount of reserves available to the banking system. Until the financial crisis, it was understood by only a few scholars that central banks cannot but just pursue defensive operations, in order to counteract the impact of the transactions going through the clearinghouse and involving the government, as central banks do their best to adjust the supply of reserves to the demand for reserves, compensating for what is now called autonomous factors (Eichner, 1986, ch. 5; Fullwiler, 2003; Bindseil, 2004).

This post-Keynesian view is best exemplified in the corridor system that has been put in place in many countries, where the target rate of interest is set in the middle of a corridor, where the bottom of the corridor is the interest rate paid on the reserves deposited by banks at the central bank, while the ceiling of the corridor is given by the interest rate that banks must pay when they borrow reserves from the central bank. Borio and Disyatat (2010) then say that reserves are decoupled from interest rates, in the sense that the interbank interest rate, that is, the overnight rate or the federal funds rate in the US, can be changed without having to change the amount of reserves in the system, simply by moving the whole corridor up or down. However, to achieve the target within the corridor, the central bank must provide the amount of reserves which is being demanded by the banking system at the target rate of interest. Thus, central banks must pursue the defensive operations mentioned in the above paragraph. Reserves are only partly decoupled from interest rates in the corridor system.

With the short-term rate of interest as the exogenous element, the causality is reversed: the demand for reserves causes and determines the supply of reserves. Thus, the mainstream money-multiplier story associated with a fractional-reserve system does not hold water any more, and in fact never did. The difference now is that the irrelevance of the story is obvious, or should be obvious to all. Even when they refer to a corridor system, textbooks are still filled with money-multiplier stories, where the amount of reserves created by the central bank allows banks to make loans and to proceed to a multiple expansion of money deposits, 
thus being totally incoherent with the rest of the story based on target interest rates. What banking systems have instead is a case of reverse causation. At best, one could speak of a credit divisor, where an expansion of bank credit eventually leads to an increase in the amount of reserves and cash supplied by the central bank.

Keynes approved of the money multiplier story, which is not surprising given his support of the exogenous money view. In fact, in the Treatise on Money, Keynes (1930a, p. 25, fn. 1) gives his full approval to the money multiplier analysis of Crick and C.A. Phillips, which at the time, was far from being an established theory. This is not an accident, as Keynes repeatedly provides support for the argument that the supply of money is some multiple of the amount of reserves being provided by the monetary authorities, arguing from the very beginning of his treatise that 'the pace [of credit creation] common to all the Member Banks is governed by the aggregate of their reserve-resources' (Keynes 1930a, p. 30). A nearly similar statement is made much further in the book, when Keynes (1930b, p. 225) says that 'the total volume of bank-money created is determined, either rigidly or within certain defined limits, the amount of the Member Banks' reserve resources'. Indeed, Keynes seems quite optimistic about the ability of the central bank to control credit creation through open-market operations when he states that 'certainly there can be no doubt that a progressive series of small inflationary open-market purchases by the Central Bank are potently, and almost invariably, effective in inducing member banks to follow suit.' (1930b, p. 254-5).

However, Keynes shows glimpses of understanding of what French central bankers in the 1970s have called the compensation thesis (Lavoie 2014, ch. 7). Keynes is aware that central banks will sterilize, as much as they can, foreign outflows or inflows, by conducting open-market operations. He is aware of the importance of the 'defensive' operations that I mentioned earlier. He is also aware that expansionary open-market operations may fail if banks are in debt vis-à-vis the central bank, as in the US case that he describes in contrast to the British system (Keynes 1930b, p. 257); hence, in that case, the amount of reserves is demand-determined and not really under the control of the central bank. This is recognized by Keynes (1930b, p. 251) when he writes that the Central Bank cannot vary the volume of its "investments" without tending to produce an opposite and compensating variation in the volume of its "advances", unless it accompanies its action with an appropriate change of Bank rate'. Thus, with these passages, his views of the monetary and banking systems are much closer to those of modern post-Keynesians.

\section{Quantitative easing}

The Global Financial Crisis has clearly shown that the money multiplier is false: it is so meaningless that one could say ironically that it is not even wrong! In addition to a number of Fed officials, as recalled in Lavoie (2010), officials at the Bank of England recently felt obliged to dismiss this money-multiplier story by recalling that 'another misconception is that the central bank determines the quantity of loans and deposits in the economy by controlling the quantity of central bank money - the so-called "money multiplier" approach' (McLeay et al. 2014, p. 15). This is not to say that central banks have no power: central bankers can certainly induce a recession by raising nominal and real interest rates; in my view however, and as it has been verified since 2008, this power is asymmetric: central banks have much less ability to kick-start the economy

How false the money multiplier and the fractional-reserve system stories are was revealed to a larger public when central banks in the US or the UK started pursuing credit easing or quantitative easing operations, by purchasing private assets or government bonds on secondary markets without taking compensating measures to sterilize these operations, thus 
leading to large increases in the size of their balance sheet. Mainstream economists expressed their fears that this would lead to a multiple expansion in the money supply, followed by large increases in inflation rates. But none of this has yet happened. In the UK in particular, the rise in the money supply for a while even happened to be smaller than the increase in bank reserves; and in the US, stunned analysts realized that the so-called money multiplier had fallen below unity. The response of mainstream economists has been that the money multiplier has collapsed temporarily, and that when it will recover its normal value in the future, when normal conditions are back, the massive amount of excess reserves will allow banks to fund excessive amounts of loans, thus finally generating the inflation or even the hyper-inflation that they had long predicted.

Fortunately, there are analysts out there who understand the money creation process. Paul Sheard (2013), a chief economist at Standard and Poor's, has written a research note that explains that 'banks cannot and do not lend out reserves'. Sheard points out that banks taken as a group cannot lend out the reserves that they hold at the central bank. Bank loans are not created out of reserves, or out of deposits. 'Credit is created literally out of thin air' (Sheard, 2013, p. 6). The causality is reversed. 'Loans create deposits, not the other way around' (ibid). For the global amount of reserves to be reduced, there has to be some transaction involving the central bank, such as the sale of an asset to the private sector by the central bank, a tax payment that goes to the account of the government at the central bank, or if banks acquire banknotes from the central bank. As a parody of an expression that Keynes once used, we can say that while banks can lend until they are blue in the face, this will in no way reduce the amount of bank reserves at the central bank. It should be pointed out that Keynes, to his credit and in contrast to several mainstream economists today, did not envisage a direct transmission mechanism going from the creation of excess reserves through QE operations to the creation of additional loans. For Keynes, the possible positive effects of QE would occur through lower interest rates, as will be shown below.

This is perfectly compatible with the post-Keynesian analysis of endogenous money. Since banks grant loans to credit-worthy borrowers and search for reserves later, the fact that banks are now flush with reserves does not mean that they will make more loans and create more deposits in the process (Fullwiler 2013). In the UK case, because the Bank of England was purchasing financial assets from non-banking agents, these agents used the proceeds of their sales to deleverage and reduce their debt, thus destroying the bank deposits that had been created when they had sold their assets to the Bank of England. This thus explains why the money supply barely increased, despite the huge increase in bank reserves.

It has been pointed out by Jan Kregel (2014) that Keynes had quite a lot to say about monetary policy in recession times and about quantitative easing and other extraordinary methods. As is well-known, before the Great Depression Keynes advocated the use of monetary policy to get the economy out of the slump, as he proposed that in 'conditions of acute slump or boom... more extreme measures will have to be involved' (Keynes 1930b, p. 369). For Keynes, these more extreme measures were simply an upgraded version of standard open-market operations: 'These extra-ordinary methods are, in fact, no more than an intensification of the normal procedures of open-market operations. I do not know of any case in which the method of open-market operations has been carried out à outrance' (Keynes 1930 b, p. 370). Keynes thought that if these extraordinary measures were pursued with sufficient determination, the central bank would be able to lower long-term interest rates and hence reduce the Wicksellian gap between investment and saving:

"My remedy in the event of the obstinate persistence of a slump would consist, therefore, in the purchase of securities by the Central Bank until the long-term market-rate of interest has been brought down to the limiting point.... It should not be beyond the power of a 
Central Bank ... to bring down the long-term market-rate of interest to any figure at which it is itself prepared to buy long-term securities." (Keynes 1930b, p. 371).

This is what a number of central banks have attempted to achieve. An alternative to this kind of extraordinary monetary policy could have been instead to set an explicit target for the long-term interest rate on government bonds. This alternative was suggested by Keynes himself in the General Theory: 'Perhaps a complex offer by the central bank to buy and sell at stated prices gilt-edged bonds of all maturities, in place of the single bank rate for short-term bills, is the most practical improvement which can be made to the technique of monetary management' (Keynes 1936, p. 206). Indeed this is what some central banks did during WW2, in particular in the US until 1951, where such an explicit long-term interest rate target was set.

Keynes was also aware that a QE policy would have an impact on overnight rates. With QE and the creation of excess reserves, overnight rates would tend to fall, as argued by modern economists who have a proper understanding of the clearing and settlement system: 'If the Central Bank supplies the member banks with more funds than they can lend at shortterm, in the first place the short-term rate of interest will decline to zero' (Keynes 1930b, p. 371).

Thus for Keynes, the main transmission mechanism of QE operations was through the change in interest rates. Another possible transmission mechanism would operate through the positive impact of $\mathrm{QE}$ on stock market prices, as was indeed observed during the Great Recession:

"If the effect of such measures is to raise the price of "equities" (e.g. ordinary shares) more than the price of bonds, no harm in a time of slump will result from this; for investment can be stimulated by its being unusually easy to raise resources by the sale of ordinary shares.... Thus I see small reasons to doubt that the Central Bank can produce a large effect on the cost of raising new resources for long term investment." (Keynes 1930b, p. 372).

Thus Keynes was a partisan of some zero-interest rate policy before it was advocated in 2008 or 2009, when he argued that central banks should 'maintain a very low level of the short-term rate of interest, and buy long-dated securities either against an expansion of Central Bank money or against the sale of short-dated securities' (1930b, p. 386). This, he thought could be achieved either by QE operations ('an expansion of central bank money'), or through credit easing operations ('against the sale of short-dated securities'), which is what a number of central banks did initially, in 2007 and 2008, as they swapped liquid short-term public assets for illiquid public or private long-term assets.

One could argue that Keynes also had in mind the 'expectations channel' that many mainstream economists relied upon during the financial crisis, as central bankers promised to keep short-term rates at low or zero levels for a determinate amount of time - the so-called forward guidance. The expectations channel appears when Keynes (1930b, p. 386) writes that 'It might be sufficient merely to produce a general belief in the long continuance of a very low rate of short-term interest'. The expectations channel is also present in the General Theory when Keynes (1936, p. 202) notes that 'the long-term rate market-rate of interest will depend, not only on the current policy of the monetary authority, but on also on market expectations concerning its future policy'.

\section{The floor system and its impact on post-Keynesian monetary theory}

Some readers may notice that there now seems to be some inconsistency between the claim, made earlier, that the supply of reserves is demand-led and the observation that central banks, through quantitative easing, were able to create large amounts of unwanted reserves. 
This discrepancy between post-Keynesian theory and actual facts can be explained by the adoption by some central banks of a modified form of the corridor system - the floor system. Checking Figure 1 below, we can say that the floor system corresponds to the case where the target interest rate set by central bank is equal to the rate of interest on reserves (the interest rate on the deposit facility at the central bank), found at the bottom of the corridor.

This floor system was adopted in the US at the end of 2008, when the Fed realized that it no longer was able to sterilize its credit easing operations, so that the only way to insure that the target interest rate would be realized was to set that target interest rate at the bottom of the corridor. ${ }^{2}$ With the banking system being overall in a position of excess reserves, that is, on the far right of Figure 1, the overnight rate will tend towards the deposit rate - the interest rate on reserves - as a bank with excess reserves will lend to a bank lacking reserves only if the interest rate is as high as the one it could obtain at no risk from the central bank. Thus, with a floor system, the central bank has the ability to fully disconnect the interest rate from the amount of reserves. The central bank can keep control of the overnight rate whatever is the amount of reserves in the economy, provided the supply of reserves is much larger than the amount being demanded by banks at the target rate of interest.

Figure 1: The corridor system

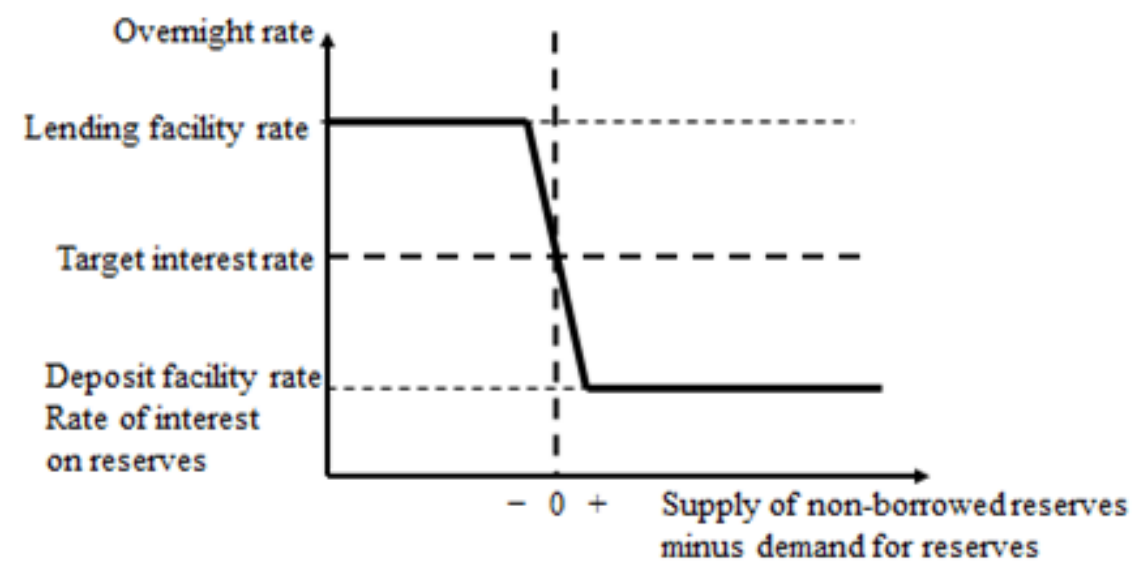

The mechanics of monetary creation and those of the floor system are not well understood by most economists. Many economists or financial observers believe that commercial banks refuse to make loans because they are getting interest payments on their reserves at the central bank. These economists don't seem to realize that in a floor system the central bank is able to set the amount of excess reserves at whatever level that it desires. Because the supply of reserves exceeds the demand for reserves, the overnight rate tends to fall, and it will drop until it hits the floor of the corridor, that is, the interest rate paid on reserves. But this is not a problem for a central bank operating within a floor system because the floor rate is the overnight rate targeted by the central bank. In such a case, the central bank has the ability to set reserves at the level of its choice because it still keeps control over the overnight interest rate. The reserves are fully decoupled from interest rates, in the sense that the central bank can change the amount of reserves without having any impact on the overnight interest rate that it is targeting, in contrast to the situation of a corridor system. The following statement by another official of the Bank of England is particularly telling:

\footnotetext{
${ }^{2}$ The floor system was in fact adopted by the Bank of Japan as early as 1996 , and it happened to be put in place in New Zealand and in Norway before the Global Financial Crisis. One could also argue that the US were under a floor regime from the World War II until 1951.
} 
"The level of commercial banks' reserves in aggregate is determined by the way we have funded the asset purchases, not by the commercial banks' own decisions. The size of banks' reserves cannot, as is frequently claimed, be a sign that they are "sitting on them". No matter how rapidly or how slowly the economy is growing, or how fast or slow the money is circulating, the aggregate amount of reserves will be exactly the same. So it should be clear that the quantity of central bank reserves held by the commercial banks is useless as an indicator of the effectiveness of Quantitative Easing." (Bean 2009, p. 4).

Speaking of the effectiveness of quantitative easing, one may wish to assess how effective it is. Quantitative easing carries with it an inherent contradiction. On the one hand those who advocate quantitative easing policies do so under the pretext that QE will induce economic agents to increase their expected rate of inflation, thus eventually raising realized rates of inflation and lowering the real rate of interest, in the hope of generating higher levels of economic activity. On the other hand, central bankers are at the same time trying to persuade financial markets that quantitative easing can be reversed in the future, so that an inflated central bank balance sheet does not mean high future inflation rates, so as to keep long-term interest rates from rising. It is not clear how these two objectives can be attained at the same time. At best, quantitative easing, as pursued, helps to sustain security prices and stock market prices, and may help to depreciate the domestic currency. At worse, quantitative easing has no effect on output and employment. Those who sell their assets to the central bank use the money to deleverage, paying down their loans.

There is a further problem with quantitative easing, one that has been noted by Keynes. With such low rates of interest, banks can run into difficulty as interest rates on their liabilities are already at zero or very close to zero already in normal times. Thus a decrease in interest yields on their assets can hurt the profitability of banks. This was pointed out in the Treatise on Money when Keynes (1930b, p. 359) argued that 'it is evident, therefore, that there is not much room for much fall in their average interest earnings without a serious reaction on their profits [those of banks]'. The warning was again repeated in the General Theory: 'Thus the rate of interest which the typical borrower has to pay may decline more slowly than the pure rate of interest, and may be incapable of being brought ... below a certain minimum figure' (1936, p. 208).

The world of monetary policy seems to be upside down. What is called conventional monetary policy is now interest-rate targeting, as it was at the time of Wicksell and of the Radcliffe committee in the late 1950s in England, and before the advent of Monetarism and the rise of Milton Friedman in the mainstream of the economic profession. Unconventional monetary policy is now quantitative targets, expressed in asset purchases or increases in the size of bank reserves. Monetary targeting in the 1970s and 1980s was used as a tool to reduce the inflation rate; now it is used in an attempt to increase the inflation rate or the expected inflation rate!

\section{Conclusion}

We have seen that many of the events or the consequences of the Global Financial Crisis were difficult to understand if one were to stick to mainstream economics. What has occurred since 2007 has forced a reconsideration of monetary theory. Some ideas that had been discarded have gone back into fashion. It is well known to students of the history of economic thought that economics is infested by fashions and fads. We have noted that many of unconventional policies pursued by central bankers could already be found in Keynes's Treatise on Money. As A.B. Cramp (1971, p. 62), a colleague of Kaldor, recalled: 'Economic ideas, the Cambridge economist D.H. Henderson once remarked, move in circles: stand in one place long enough, 
and you will see discarded ideas come round again [...]. And nowhere is this more true than in respect to monetary theory and the associated theory of monetary policy'.

Macroeconomic theory also is in need of a reinterpretation. A number of firmly-held beliefs are now being questioned. One such belief is the claim that monetary policy is the main tool of stabilization and that fiscal policy should only play a very minor role. There is a realization among economists, although much less so among politicians, that there are severe limits to how much monetary policy can achieve in periods of recession or stagnation, and that expansionary fiscal policy is a necessary tool to boost the economy. Monetary policy has limits. The role and power of monetary policy have been exaggerated while those of fiscal policy have been overly minimized (Arestis 2015; Nevile and Kriesler 2014). There needs to be a new emphasis on fiscal policy.

The irony is that Keynes himself had made the transition, 80 years ago. Whereas in the Treatise on Money Keynes was still confident about the clout of expansionary monetary policy, as we have seen with our discussion of the extreme open-market operations that Keynes was advocating, by the time he had finished writing the General Theory Keynes was much enthusiastic, recognizing that 'if, however, we are tempted to assert that money is the drink that stimulates the system to activity, we must remind ourselves that there may be several slips before the cup and the lip' (1936, p. 173). This led him to conclude that 'for my own part, I am now somewhat sceptical of the success of a merely monetary policy directed towards influencing the rate of interest. I expect to see the State ... taking ever greater responsibility for directly organising investment' (1936, p. 164).

Keynes (1936, p. 164) thought that the negative animal spirits generated by an economic crisis would 'be too great to be offset by any practicable changes in the rate of interest'. In a sense this corresponds to the liquidity trap as understood by Krugman (1998), meaning that nominal rates of interest would need to fall way below zero to get the economy back on track - an impossible solution. Thus the only way out which is left is fiscal policy and public works, as Keynes (1936, p. 129) emphasized, for otherwise society accepts to waste existing capital and labour resources, and even future ones if there are hysteresis and superhysteresis effects, a possibility that post-Keynesians have always underlined and that is now accepted by a number of New Keynesians.

\section{References}

Arestis, P. (2015). "Current and future European Central Bank monetary policy", Brazilian Keynesian Review, 1(1), 4-17.

Ball, L. M. (2014). "The case for a long run inflation target of four percent", IMF working paper WP/14/92, https://www.imf.org/external/pubs/ft/wp/2014/wp1492.pdf

Bank of Canada. (2011). "Renewal of the Inflation-Control Target: Background Information", October, content/uploads/2011/11/background_nov11.pdf http://www.bankofcanada.ca/wp-

Bean, C. (2009). "Quantitative Easing - An interim report", Speech to the London Society of Chartered Accountants, 13 October, http://www.bis.org/review/r091019c.pdf

Bindseil, U. (2004). Monetary Policy Implementation: Theory, Past, and Present, Oxford: Oxford University Press.

Borio, C.; P. Disyatat. (2010). "Unconventional monetary policies: an appraisal", Manchester School, 78, Supplement, September, 53-89. 
Cardim de Carvalho, F. J. (2013). "Keynes and endogenous money", Review of Keynesian Economics, 1 (4), 431-446.

Clinton, K. (2006). "Inflation targeting in Canada: Origins, conduct, accountability, lessons", paper presented at a conference at Sciences Po Bordeaux, May 2006. .

Cramp, A. B. (1971). "Monetary policy: Strong or weak?", in N. Kaldor (ed.), Conflicts in Policy Objectives, Oxford: Basil Blackwell, pp. 62-74.

Eichner, A. S. (1986). Toward a New Economics: Essays in Post-Keynesian and Institutionalist Theory, London: Macmillan.

Fullwiler, S. T. (2003). "Timeliness and the Fed's daily tactics", Journal of Economic Issues, 37 (4), December, 851-880.

Fullwiler, S. (2013). "An endogenous money perspective on the post-crisis monetary policy debate", Review of Keynesian Economics, 1 (2), Summer, 171-194.

Godley, W. (1997). "Macroeconomics without equilibrium or disequilibrium", working paper No. 205, Levy Economics Institute of Bard College. Reproduced in M. Lavoie and G. Zezza (eds), The Stock-flow Consistent Approach: Selected Essays of Wynne Godley, Basingstoke: Palgrave Macmillan, pp. 90-122.

Kaldor, N. (1982). The Scourge of Monetarism, Oxford: Oxford University Press.

Keynes, J. M. (1930a). A Treatise on Money, Volume 1, The Pure Theory of Money, New York: Harcourt Brace and Company.

Keynes, J. M. (1930b). A Treatise on Money, Volume 2, The Applied Theory of Money, New York: Harcourt Brace and Company.

Keynes, J. M. (1936). The General Theory of Employment, Interest and Money, London: Macmillan.

Kregel, J. (2014). "Liquidity preference and the entry and exit to ZIRP and QE", Policy Note 2014/5, Levy Economics Institute of Bard College.

Krugman, P. (1998). "It's baaack! Japan's slump and the return of the liquidity trap", Brookings Papers on Economic Activity, 2, 137-187.

Lavoie, M. (2010). "Changes in central bank procedures during the subprime crisis and their repercussions on monetary theory", International Journal of Political Economy, 39 (3), Fall, 3-23.

Lavoie, M. (2014). Post-Keynesian Economics: New Foundations, Cheltenham: Edward Elgar.

McLeay, M.; Radia, A.; Thoms, R. (2014). "Money creation in the modern economy", Bank of England Quarterly Bulletin, $1^{\text {st }}$ Quarter, 14-27.

Moore, B. J. (1988). Horizontalists and Verticalists: The Macroeconomics of Credit Money, Cambridge: Cambridge University Press.

Neville, J. W.; Kriesler, P. (2014). "A bright future can be ours! Macroeconomic policy for noneurozone Western countries", Cambridge Journal of Economics, 38 (6), 1453-1470.

Patinkin, D. (1948). "Flexibility and full employment", American Economic Review, 38 (4), 543564.

Peach, R.; Rich, R.; Cororation, A. (2011), "How does slack influence inflation", Federal Reserve Bank of New York Current Issues in Economics and Finance, 17 (3), 1-7. 
Poole, W. (1970). "Optimal choice of monetary policy instruments in a simple stochastic macro models", Quarterly Journal of Economics, 84 (2), May, 197-216.

Rymes, T. K. (1991). "The case for a discretionary, politically responsible central bank", in T.K. Rymes (ed.), Welfare, Property Rights and Economic Policy: Essays and Tributes in Honour of H. Scott Gordon, Ottawa: Carleton University Press, pp. 133- 153.

Seccareccia, M.; Lavoie, M. (2010). "Inflation targeting in Canada: myth and reality", in G. Fontana, J. McCombie and M. Sawyer (eds), Macroeconomics, Finance and Money: Essays in Honour of Philip Arestis, Basingstoke: Palgrave Macmillan, pp. 35-53.

Sheard, P. (2013). "Repeat after me: Banks do not and cannot lend out reserves", Research Note, Standard and Poor's Rating Services.

Tily, G. (2007). Keynes's General Theory, the Rate of Interest and 'Keynesian' Economics: Keynes Betrayed, Basingstoke: Palgrave Macmillan. 